\title{
Dehydrated melon containing antioxidants and calcium from grape juice
}

\author{
Hulda N. M. Chambi, Julia D. Arid, Flávio L. Schmidt
}

Department of Food Technology, School of Food Engineering, State University of Campinas, UNICAMP, Campinas, SP 13083-862, Brazil

Corresponding author: Flávio L. Schmidt, PhD, Department of Food Technology, School of Food Engineering, State University of Campinas, UNICAMP, Campinas, SP 13083-862, Brazil

Submission Date: August 5, 2016, Accepted Date: November 26, 2016, Publication Date: November 30, 2016

Citation: Chambi H.N.M., Arid J.D., Schmidt F.L. Dehydrated melon containing antioxidants and calcium from grape juice. Functional Foods in Health and Disease 2016; 6(11):718-734

\begin{abstract}
Background: Grape juice has a high antioxidant potential, capable of fighting oxidative processes in the body. The juice is mainly marketed in its concentrated form, which has a high content of glucose and fructose. The juice concentrate may then be used as an osmotic agent to dehydrated fruit with a relatively short shelf-life at room temperature, such as melon. The osmotic dehydration process can also be combined with conventional drying in order to further reduce the water activity $\left(a_{w}\right)$ of the product. Finally, the antioxidant-rich melon meets the consumers' demand for foods which contain ingredients that may impart health benefits.
\end{abstract}

Results: Melon dehydrated by osmotic process at 200, 400 and 600 mbar, using grape juice concentrate (GJC), showed no significant differences in physical characteristics $\left(a_{w},{ }^{\circ}\right.$ Brix, and moisture content). Higher efficiency was observed when dehydration was performed at 200 mbar. After osmotic dehydration with GJC, both plasmolysis of the melon cells and an increase in intercellular spaces were observed by optical microscopy, with no negative impact on the mechanical properties (True stress, Hencky's strain and deformability modulus). Calcium present in GJC was impregnated into the melon matrix, thus contributing with the mineral composition and mechanical properties of the final product. No significant differences were observed for the antioxidant capacity of melon dehydrated both with GJC and GJC followed by air-drying at 50 and $70^{\circ} \mathrm{C}$. This demonstrates that it is possible to combine the two processes to obtain a product with intermediate moisture without decreasing its antioxidant capacity. The samples scored above the acceptable limit $(>5)$ varying between like slightly to like moderately, resulting in a purchase intent with average scores between 3 (maybe/maybe not buy) and 4 (probably would buy). 
Conclusions: A product with intermediate water activity, acidic, firm, high antioxidant capacity, rich in calcium and in naturally occurring sugars, and potential sensory acceptance can be obtained using grape juice concentrate in the osmotic dehydration process, followed by airdrying process.

Keywords: osmotic dehydration, air-drying, fruit juice, optical microscopy, antioxidants, calcium.

\section{BACKGROUND}

Grape juice is considered a product with high antioxidant potential, capable of combating oxidative processes in the organism [1,2]. Several studies have shown that grape juice consumption can positively influence risk factors associated with cardiovascular health, cancer, neurodegenerative diseases, and age-related cognitive decline [3-5]. Grape juice is marketed mostly in the concentrated form, and contains a high content of glucose and fructose, which are widely used in osmotic dehydration processes $[6,7]$. Thus, grape juice concentrate can be used as an osmotic agent to dehydrate fruits with relatively short shelf-life at room temperature, such as melon.

Grape mushand grape juice concentrate were used as osmotic agents for dehydration of kiwi and yellow melon, with high dehydration efficiency when compared with sucrose solution $[8,9]$. The processes were conducted under reduced pressure with a vacuum pulse application [8] and constant pressure [9]. The mass transfer during melon dehydration with grape juice concentrate and sucrose solution has been modeled by Fick's and Page's equations [9]. Besides the improvement in the dehydrating efficiency, the antioxidants in grape juice can also be incorporated into the melon matrix, resulting in products with distinct characteristics, attracting consumers' interest.

Despite the advantages of osmotic dehydration (OD), the mass transfer (water loss and solute gain) can lead to changes in texture, thereby changing the cellular structure of the product, depending on the conditions of the process and the product's characteristics [10]. Some authors investigated the OD process in strawberry slices at different process times, and found that the cell damage was enhanced with the increase in time [11]. These changes alter the mechanical properties of the fruit, and thus its appearance and texture, influencing consumers' acceptance.

The OD can also be combined with other preservation methods such as freezing or drying. With respect to the freezing process, the use of grape juice concentrate can improve the product resistance to damage by freezing, since the low molecular mass solutes in the juice have a cryoprotectant effect [12]. Additionally, the OD process reduces the drying time and limits the undesirable effects of heat on the quality of the final product, besides preventing subsequent structural damages [13]. Furthermore, drying is essential to remove water to a microbiological safe level. Finally, the consumption of foods enriched with natural antioxidants can protect against the oxidative stress related diseases or improve cognitive performance in humans [14].

Consequently, the study aimed to evaluate the effect of different osmotic pressure on cell structure and mechanical properties of yellow melon, using grape juice concentrate as an osmotic agent; to assess the antioxidant capacity, calcium content, and sensory acceptance of the product; and to dehydrate melon with grape juice concentrate followed by conventional drying at 50 and 
$70^{\circ} \mathrm{C}$. In this context, the use of osmotic dehydration process can ensure a final product with better sensory quality, more uniform characteristics, and increased shelf life.

\section{METHODS}

\section{Material}

Melons (Cucumis melo L. var. inodorus) grown in Mossoro region (RN, Brazil) were obtained from a local market (CEASA, Campinas, Brazil). Fruits were selected based on skin color (yellow), pulp (whitish green), appearance (similar size and shape), and manually washed and peeled. Grape juice concentrate was purchased from the company Golden Sucos (RS, Brazil), and diluted with water to $60^{\circ}$ Brix. For comparison purposes, sucrose solution $\left(60^{\circ}\right.$ Brix $)$ was prepared from commercial sugar. Table 1 shows the characteristics of both osmotic solutions and melons [9].

Table 1. Physicochemical characteristics of melon and osmotic solutions.

\begin{tabular}{llll}
\hline Characteristics & Melon & $\begin{array}{l}\text { Sucrose } \\
\text { solution }\end{array}$ & GJC \\
\hline${ }^{\circ}$ Brix $\left(25^{\circ} \mathrm{C}\right)$ & $10.84 \pm 0.84$ & 60 & 60 \\
Titratable acidity $\left(\mathrm{g}^{1} / 100 \mathrm{~g}\right)^{2}$ & $0.11 \pm 0.01$ & $0.0041 \pm 0.0005$ & $2.084 \pm 0.011$ \\
Reducing sugar $(\mathrm{g} \text { glucose } / 100 \mathrm{~g})^{2}$ & $3.96 \pm 0.35$ & $0.163 \pm 0.042$ & $50.06 \pm 1.06$ \\
$\mathrm{pH}\left(25^{\circ} \mathrm{C}\right)$ & $5.87 \pm 0.19$ & $7.31 \pm 0.17$ & $3.03 \pm 0.02$ \\
$a_{w}{ }^{3}\left(25^{\circ} \mathrm{C}\right)$ & $0.9928 \pm$ & $0.8769 \pm 0.0005$ & $0.8382 \pm$ \\
& 0.0019 & & 0.0028 \\
Moisture $(\%)$ & $88.45 \pm 0.89$ & n.d. & n.d. \\
\hline
\end{tabular}

${ }^{1} \mathrm{~g}$ citric acid for melon and sucrose solution and $\mathrm{g}$ tartaric acid for grape juice; ${ }^{2}$ wet basis; n.d., not determined; ${ }^{3} \mathrm{a}_{\mathrm{w}}$ $=$ water activity.

\section{Osmotic dehydration}

Osmotic dehydration (OD) was carried out in equipment with natural circulation, as described by Chambi et al. [9]. Melon samples (cylinders $11 \mathrm{~mm}$ diameter and $10 \mathrm{~mm}$ high) were subjected to OD using osmotic solution $\left(60^{\circ} \mathrm{Brix}\right)$ at $40^{\circ} \mathrm{C}$, and fruit: osmotic solution ratio of $1: 10$, under different absolute pressures $(200,400$, and 600 mbar) for 60 minutes. All OD process were performed in triplicate. Antifoam $\left(0.3 \mathrm{mg} \mathrm{g}^{-1}\right)$ Xiameter AFE-0010 (D'Altomare Química Ltda, São Paulo, Brazil) was added to the grape juice to prevent foam formation.

\section{Air-drying}

Air-drying studies were carried out after the osmotic dehydration. Melon cubes (10 mm sides) were kept in grape juice concentrate $\left(60^{\circ} \mathrm{Brix}\right)$ at $40^{\circ} \mathrm{C}$ under $600 \mathrm{mbar}$ for 60 minutes, at a ratio of 1:5, fruit : osmotic solution, without addition of antifoam. No significant differences were observed in the physical characteristics $\left(\mathrm{a}_{\mathrm{w}}\right.$, ${ }^{\circ}$ Brix, and moisture content) of these samples when compared with samples dehydrated using fruit to solution ratios of 1:7 and 1:10 (data not shown). After removal from the grape juice concentrate, the dehydrated cubes were drained, rinsed with distilled water, and placed on absorbent paper to remove the excess of solution, and transferred to forced-air oven at 50 and $70^{\circ} \mathrm{C}$ until reaching $\mathrm{a}_{\mathrm{w}} \sim 0.7$ (at $25^{\circ} \mathrm{C}$ ). Melon dehydrated with GJC (dehydrated melon 1) and with GJC followed by air-drying process at 50 and $70^{\circ} \mathrm{C}$ 
(dehydrated melons 2 and 3, respectively) were evaluated for the antioxidant capacity, calcium content, and sensory acceptance.

\section{Physical Characteristics}

Soluble solids content was measured by direct readings in an automatic refractometer, model r2i300 (Reichert, USA) at $25^{\circ} \mathrm{C}$. Moisture content was determined by gravimetric method. The $\mathrm{a}_{\mathrm{w}}$ was measured using a Dew Point Water Activity Meter model 4TE-Aqualab (Decagon devices Inc., USA) at $25^{\circ} \mathrm{C}$. Depression of water activity $\left(\Delta \mathrm{a}_{\mathrm{w}}\right)$ was calculated by the Equation 1 [15]. All determinations were carried out in triplicate.

$$
\Delta a_{w}=\left(\frac{\left.a_{w(\text { fresh fruit })}-a_{w} \text { (osmodehydrated fruit }\right)}{\left.a_{w} \text { (fresh fruit }\right)}\right) \times 100
$$

\section{Process effectiveness}

The process effectiveness (PE) was calculated by the ratio of water loss (WL) to the solute gain (SG) at the end of osmotic dehydration [16] (Equations 2, 3 and 4).

$$
\begin{aligned}
& P E=W L / S G \\
& W L=\frac{M_{f} \cdot X_{f}-M_{o} \cdot X_{o}}{M_{o}} \\
& S G=\frac{M_{f} \cdot S_{f}-M_{o} \cdot S_{o}}{M_{o}}
\end{aligned}
$$

$W L$ and $S G$ were expressed in grams per gram of initial fresh melon mass; $M_{f}$ and $M_{o}$ are the final and initial samples mass (g) respectively; $X_{f}$ and $X_{o}$ are the final and initial moisture content ( $\mathrm{g} \mathrm{g}^{-1}$ melon) respectively; and $S_{f}$ and $S_{o}$ are the final and initial soluble solids content $\left(\mathrm{g} \mathrm{g}^{-1}\right.$ melon) respectively.

\section{Mechanical properties}

The mechanical properties were evaluated by uniaxial compression in a TA.XT2i texture analyzer (Stable Micro Systems, UK), with a flat-end cylindrical probe (40 $\mathrm{mm}$ diameter). The probe was lubricated with silicone oil to avoid the effects of the plate-sample friction during compression. Compression tests were done at $1 \mathrm{~mm} \mathrm{~s}^{-1}$ until $80 \%$ of sample deformation [17]. From the force-deformation data, true stress $(\sigma)$ and Hencky's strain $(\varepsilon)$ were calculated according to Equations 5 to 7 [18] respectively.

$$
\begin{aligned}
& \sigma=F_{t} / A_{t} \\
& \mathrm{~A}_{\mathrm{t}}=\frac{\mathrm{H}_{\mathrm{o}} \mathrm{A}_{\mathrm{o}}}{\mathrm{H}_{\mathrm{t}}} \\
& \varepsilon=-\ln \left[\frac{\mathrm{H}_{\mathrm{t}}}{\mathrm{H}_{\mathrm{o}}}\right]
\end{aligned}
$$


Where $F_{t}$ and $A_{t}$ are the compression force and the contact area at the time of compression $t$, respectively. $A_{o}$ is the initial specimen area, $H_{t}$ and $H_{o}$ is the height of the cylinder at the time of compression $t$ and $t=0$, respectively.

Stress-strain curves show an initiating effect resulting from a non-ideal flat surface of samples. This effect was in failure strain $<0.04$ (fresh melon) and $<0.1$ (dehydrated melon); as a result, it was considered negligible for the calculation of the mechanical parameters at failure. Deformability modulus was taken from the slope of initial linear zone of stress-strain curve after the initiating effect. For each process, seven samples were analyzed, and the means were used to calculate the final average. Whereas texture is not uniform among fruits, values of the three parameters were normalized as the ratio between values for the both treated and untreated samples.

\section{Structural observation}

Three samples were removed from the stirred vessels for structural observation at the same sampling times of the textural measurements. One rectangular slab with $1 \mathrm{~mm}$ thickness was gently cut parallel to the major axis of each cylinder, and in its middle length with a razor blade. The slabs were fixed for $48 \mathrm{~h}$ in $4 \%$ glutaraldehyde solution, $0.2 \mathrm{M}$ Potassium phosphate, dibasic, $0.1 \mathrm{M}$ citric acid monohydrate, and $4 \%$ sucrose. Afterwards, the slabs were dehydrated in a graded alcohol series of $10,30,50$, and $70 \%$ containing sucrose $4 \%$, for $1 \mathrm{~h}$ each. The dehydrated samples were immersed into pre-infiltration solution $(100 \%$ alcohol + hydroxyethyl methacrylate resin mixed with $10 \%$ benzoyl peroxide, 1:1 ratio) during 3 days, followed by immersion in infiltration solution (hydroxyethyl methacrylate resin mixed with $10 \%$ benzoyl peroxide) for 3 days, in cooling environment. The samples were then placed in Teflon moulds containing approximately $1.5 \mathrm{~mL}$ infiltration solution and dimethyl sulfoxide (hardener) in a ratio of 15:1 (v/v). Polymerization was completed at room temperature within $16 \mathrm{~h}$. The polymerized blocks were sectioned (thickness $7 \mu \mathrm{m}$ ) using a rotary microtome, distended on slides, and stained with aqueous $0.05 \%$ toluidine blue in sodium acetate buffer $(\mathrm{pH}=4.7)$. The samples were examined using an Olympus BX 51 light microscope (Olympus Optical Co., Tokyo, Japan) [17, 19].

\section{Antioxidant capacity \\ Sample preparation}

Fresh melon was ground in a blender coupled with a convenient filter accessory and filtered again through a cotton layer. Grape juice concentrate $(0.2 \mathrm{~g})$ was dispersed in $5 \mathrm{~mL}$ distilled water, and $5 \mathrm{~mL}$ ethanol were added. Dehydrated melon was ground in a mortar containing liquid nitrogen, dispersed $(0.5 \mathrm{~g})$ in $5 \mathrm{~mL}$ water, kept at rest for $10 \mathrm{~min}$, and5 $\mathrm{mL}$ ethanol were added to the dispersion and sonicated for $20 \mathrm{~min}$. The extracts were centrifuged at $13,000 \mathrm{xg}$ for $10 \mathrm{~min}$ at $10^{\circ} \mathrm{C}$, and the supernatant was separated for analysis. All procedures were performed in a dark room at $20^{\circ} \mathrm{C}$.

\section{ABTS}

ABTS assay was based on the method of Re et al. [20]. ABTS radical cation was produced by reacting $7 \mathrm{mM}$ ABTS solution with $2.45 \mathrm{mM}$ potassium persulphate during $16 \mathrm{~h}$ in the dark at 
room temperature. The radical ABTS solution was diluted with ethanol to an absorbance of $0.72 \pm 0.02$ at $734 \mathrm{~nm}$, and $4.95 \mathrm{~mL}$ of this solution was mixed with $50 \mu \mathrm{L}$ of sample or Trolox standard $(0-2000 \mu \mathrm{M}$ in ethanol). The absorbance was measured at $734 \mathrm{~nm}$ at exactly $6 \mathrm{~min}$. Results were expressed as Trolox equivalent antioxidant capacity.

\section{DPPH}

DPPH assay was based on the method of Brand-Willians et al. [21]. In the dark, $50 \mu \mathrm{L}$ of sample or Trolox standard $(0-2000 \mu \mathrm{M}$ in ethanol) were added to $4.95 \mathrm{~mL}$ of $0.06 \mathrm{mM} \mathrm{DPPH}$ solution (in ethanol) and the reaction was kept for $16 \mathrm{~h}$. This time was necessary to achieve constant concentration of remaining DPPH for grape juice concentrate, and was used for all assays. After the reaction, the absorbance was measured at $517 \mathrm{~nm}$, and the results were expressed as Trolox equivalent antioxidant capacity.

\section{ORAC}

ORAC assay was performed as described by Ou et al. [22] for hydrophilic antioxidants using a Fluorescence microplate reader SynergyHT, Biotek (Winooski, USA) with an excitation filter at $485 \mathrm{~nm}$ and an emission filter at $528 \mathrm{~nm}$, under automatic shaking and temperature control. In dark, $25 \mu \mathrm{L}$ sample diluted in phosphate buffer, blank, or Trolox standard (0-50 $\mu \mathrm{M}$ in phosphate buffer) were added to black microplates of 96-well, mixed with $150 \mu \mathrm{L}$ fluorescein solution $(111.2 \mathrm{nM})$ and incubated at $37^{\circ} \mathrm{C}$ for $30 \mathrm{~min}$. With a multichannel pipettor, $25 \mu \mathrm{L}$ AAPH $(0.153$ M) were added to the wells to reach a final volume $200 \mu \mathrm{L}$ in each well. The plate was immediately transferred to the plate reader and the fluorescence was measured every minute for 2 hours, with total fluorescence decay of $70 \pm 5 \mathrm{~min}$ for all samples and standards. The net Area Under the Curve (AUC) of fluorescence decay over time ( $\left.\mathrm{AUC}_{\text {sample }}-\mathrm{AUC}_{\mathrm{blank}}\right)$ of the standards and samples were determined by Gen5TM 1.11 data analysis software. ORAC values were expressed as Trolox equivalent antioxidant capacity.

\section{Calcium}

Calcium was measured by atomic absorption spectroscopy in a PerkinElmer AAnalyst 200 spectrophotometer (Shelton, USA) using a hollow cathode lamp for calcium (422.7 nm) and an acetylene-air flame. Calcium standard solution (1000 $\left.\mathrm{mg} \mathrm{L}^{-1}\right)$ (Sigma) was diluted with 2\% (v/v) $\mathrm{HNO}_{3}$ (Sigma) to obtain working standards varying from 0.5 to $5 \mathrm{mg} \mathrm{L}^{-1}$. Instrumental parameters and sample preparation were made according to Boen et al. [23] with some modifications. The samples $(\sim 1.0 \mathrm{~g})$ were mixed with $4 \mathrm{~mL}$ of $69 \% \mathrm{HNO}_{3}$ and heated in a digestion block at $110^{\circ} \mathrm{C}$ during 2 hours. After cooling, $2 \mathrm{~mL}$ of $69 \% \mathrm{HNO}_{3}$ and $2 \mathrm{~mL}$ of $30 \%$ $\mathrm{H}_{2} \mathrm{O}_{2}$ were added to tubes containing the dehydrated melon and GJC samples, while $1 \mathrm{~mL}$ of $30 \%$ $\mathrm{H}_{2} \mathrm{O}_{2}$ was added to tubes containing fresh melon. These samples were heated at $130{ }^{\circ} \mathrm{C}$ during 2 hours. These conditions led to a complete mineralization of the samples. Mineralized samples were quantitatively transferred to volumetric flasks of $10 \mathrm{~mL}$ (for fresh melon) and $25 \mathrm{~mL}$ (for dehydrated melon and GJC) and the volumes completed with ultra-pure deionized water (Arium comfort I ultra-pure water system, Sartorius, Gottingen, Germany). When necessary, samples were diluted with ultra-pure water to obtain absorbance readings between 0.1 and 0.2 . 
Lanthanum $\left(0.5 \% \mathrm{w} \mathrm{V}^{-1}\right)$ was added to the samples and standards to avoid phosphate interference. Before readings, samples were passed through a quantitative filter (Type 3551, Nalgon). Analysis was performed in triplicate. All materials used for the experiments were rinsed with $10 \%$ nitric acid and ultra-pure water.

\section{Sensory evaluation}

Sensory evaluation of dehydrated melon was carried out in standardized individual booths, in the Sensory Laboratory of the Department of Food Technology, UNICAMP (São Paulo, Brazil), under controlled conditions (lighting and temperature), one day after production. Acceptance test was performed for the attributes aroma, flavor, texture, color, and overall impression using a nine-point structured hedonic scale ( $1=$ Dislike extremely, 5=Neither like nor dislike, 9=Like extremely), and purchase intention was assessed using a five-point structured hedonic scale ( $1=$ definitely would not buy, $5=$ definitely would buy). Samples were given to each judge in a completely randomized order, served on white plastic cups, and labeled with three digit random numbers [24]. Water was provided for palate cleansing between samples. The panelist consisted of 28 male and 32 female aged from 18 to 50 years $(<30$ years $=93 \%)$. The panelist included students, professors, and staff members of the School of Food Engineering who have prior test experience, as this type of test is carried out several times during the year. This evaluation was permitted to identify trends and provide direction to the research. This research is in accordance with the ethical research on human beings and was approved by the Research Ethics Committee of State University of Campinas - UNICAMP, Brazil, under the number CAAE 41682715.3.0000.5404.

\section{Statistical analysis}

Experimental results were analyzed by ANOVA and Tukey's multiple test at $95 \%$ confidence level using the statistical program Statistical Analysis Systems (SAS).

\section{RESULTS AND DISCUSSION}

\section{Physical characteristics}

No significant changes were observed for the parameters soluble solids, moisture, and water activity (Table 2) of melon dehydrated with grape juice concentrate or sucrose solution, regardless of the pressure applied to the OD process. The use of GJC as an osmotic agent resulted in a product with higher soluble solids, lower moisture, and lower $a_{w}$ when compared to melon dehydrated with sucrose solution for all pressures used. The water activity lowering capacity $\left(\Delta a_{w}\right)$ of grape juice in melon at different pressures for 1 hour at $40^{\circ} \mathrm{C}$ was close to the values obtained for guava $\left(\Delta a_{w}=3.55 \%\right)$ and apple $\left(\Delta a_{w}=4.08 \%\right)$ respectively $[25,26]$. These fruits were dehydrated in sucrose solution $\left(60^{\circ} \mathrm{Brix}\right)$ and maltose syrup $\left(56 \% \mathrm{w} \mathrm{w}^{-1}\right)$ for $5 \mathrm{~h}$ and 6 $\mathrm{h}$ at 40 and $20^{\circ} \mathrm{C}$, using fruit : osmotic solution ratio of 1:45 and 1:20, with vacuum pulse (absolute pressure of 100 mbar) and atmospheric pressure, both under constant stirring [25, 26]. Moreover, $\Delta a_{w}$ was greater than the maximum values obtained for apple $\left(\Delta \mathrm{a}_{\mathrm{w}}=1.88 \%\right)$, melon $\left(\Delta \mathrm{a}_{\mathrm{w}}=0.91 \%\right)$, and mango $\left(\Delta \mathrm{a}_{\mathrm{w}}=0.61 \%\right)$ subjected to pulse vacuum osmotic dehydration (absolute pressure from 326 to $407 \mathrm{mbar}$ ) for $20 \mathrm{~min}$ using sucrose solution at 50 and $57^{\circ} \mathrm{Brix}$, at 
$25^{\circ} \mathrm{C}$ and fruit : osmotic solution ratio of $1: 10$ [15]. In addition to this study, only one study reported a high water activity lowering capacity $\left(\Delta a_{w}=5.6 \%\right)$ when kiwi was dehydrated in grape mushat $63^{\circ}$ Brix $\left(a_{w}=0.789\right)$ during $3 \mathrm{~h}$ at $35^{\circ} \mathrm{C}$ with vacuum pulse application (50 mbar absolute pressure) for 5 minutes and recirculation rate of $1 \mathrm{~m}^{3} \mathrm{~h}^{-1}$ [8]. These observations demonstrate that the OD process with GJC can decrease water activity of the product in a shorter period, using lower volumes of osmotic solution. The significant reduction of $a_{w}$ of melon can be due to the low GJC water activity $\left(a_{w}=0.838\right)$ (Table 1$)$, the smaller molecular size of the reducing sugars in the juice (facilitating their incorporation), the reduced pressure applied to the process, besides the natural circulation in the equipment [9].

Table 2. Physical characteristics of OD melon with sucrose solution (SS) and grape juice concentrate (GJC) at different vacuum pressures

\begin{tabular}{|c|c|c|c|c|}
\hline \multirow{2}{*}{$\begin{array}{c}\text { Pressure } \\
\text { (mbar) }\end{array}$} & \multicolumn{2}{|c|}{ Soluble solids $\left(\mathbf{g ~ 1 0 0}^{-1} \mathbf{g}^{-1}\right.$ melon) } & \multicolumn{2}{c|}{ Moisture (\%) } \\
\cline { 2 - 5 } & SS & GJC & SS & GJC \\
\hline 200 & $27.8 \pm 1.2^{\mathrm{aA}}$ & $30.9 \pm 1.6^{\mathrm{aA}}$ & $73.5 \pm 1.1^{\mathrm{aA}}$ & $67.1 \pm 1.6^{\mathrm{aB}}$ \\
\hline 400 & $27.3 \pm 0.6^{\mathrm{aB}}$ & $29.6 \pm 0.5^{\mathrm{aA}}$ & $72.9 \pm 0.4^{\mathrm{aA}}$ & $68.2 \pm 0.4^{\mathrm{aB}}$ \\
\hline 600 & $27.8 \pm 0.1^{\mathrm{aA}}$ & $28.8 \pm 0.5^{\mathrm{aA}}$ & $72.7 \pm 0.9^{\mathrm{aA}}$ & $68.7 \pm 0.8^{\mathrm{aB}}$ \\
\hline \multirow{2}{*}{$\begin{array}{c}\text { Pressure } \\
(\mathbf{m b a r})\end{array}$} & \multicolumn{2}{|c|}{$\mathbf{a}_{\mathbf{w}}$} & \multicolumn{2}{|c|}{$\Delta \mathbf{a}_{\mathbf{w}}(\%)$} \\
\cline { 2 - 6 } & $\mathrm{SS}$ & $\mathrm{GJC}$ & $\mathrm{SS}$ & $\mathrm{GJC}$ \\
\hline 200 & $0.979 \pm 0.002^{\mathrm{aA}}$ & $0.963 \pm 0.002^{\mathrm{aB}}$ & $1.4 \pm 0.1^{\mathrm{aB}}$ & $2.9 \pm 0.1^{\mathrm{aA}}$ \\
\hline 400 & $0.976 \pm 0.001^{\mathrm{aA}}$ & $0.951 \pm 0.003^{\mathrm{aB}}$ & $1.6 \pm 0.3^{\mathrm{aB}}$ & $4.4 \pm 0.4^{\mathrm{aA}}$ \\
\hline 600 & $0.973 \pm 0.006^{\mathrm{aA}}$ & $0.966 \pm 0.005^{\mathrm{aA}}$ & $2.0 \pm 0.7^{\mathrm{aA}}$ & $3.6 \pm 0.6^{\mathrm{aA}}$ \\
\hline
\end{tabular}

Lowercase letters in the same column and capital letters in the same line (within the same parameter) indicate significant differences $(\mathrm{p}<0.05)$.

\section{Process effectiveness}

The OD process was more effective ( $>$ WL/ SG) at 200 mbar (Table 3) using GJC as an osmotic agent. The decrease in absolute pressure led to an increase in movement of osmotic solution within the equipment, which was more pronounced for GJC. An increase in liquid volume in the cooling system was also noted due to water evaporation, which was also higher for GJC. Water evaporation is effective in avoiding excessive dilution of the osmotic solution during OD, allowing working with osmotic solution of $\sim 59^{\circ}$ Brix, which was adjusted to $60^{\circ}$ Brix using GJC $\left(68^{\circ}\right.$ Brix $)$ at the end of each process. The motion of the solution at 200 mbar results from the collision of water molecules at temperature $\left(40^{\circ} \mathrm{C}\right)$ close to the boiling point of water $\left(\sim 62^{\circ} \mathrm{C}\right)$ at this pressure, which may have contributed to a greater melon water loss at $200 \mathrm{mbar}$. The increase in fluid movement and the presence of proteins and polysaccharides in grape juice [27] resulted in high foaming, especially at 200 and 400 mbar. Proteins may have been adsorbed at the liquid/gas interface due to their amphiphilic feature, while the polysaccharides increased the interface viscosity, thereby reducing the liquid drainage rate. For these reasons, an antifoam agent was used in all processes. 
Although high dehydration efficiency was observed (higher WL and lower SG) at $200 \mathrm{mbar}$, no significant differences were observed in ${ }^{\circ}$ Brix, moisture, and $a_{w}$ of the dehydrated melon when compared to the samples subjected to OD at 400 and $600 \mathrm{mbar}$ (Table 2), once the solute gain at 400 and 600 mbar was greater than at 200 mbar. These results are interesting because the solutes may contain antioxidants from grape juice, which can be better incorporated at high absolute pressure.

The use of GJC as osmotic agent is an alternative to improve the effectiveness of the process, and to obtain a product with lower water activity when compared to the sucrose solution. GJC has water activity lower than sucrose solution (Table 1) at the same solute concentration, and therefore higher osmotic pressure. Thus, the chemical potential gradient between water in the liquid phase of the melon cell and water in grape juice will be higher than the gradient created with the sucrose solution, resulting in further water loss for the first osmotic agent. The lower $a_{w}$ of GJC is due to its complex composition containing mainly low molecular weight solutes ( 150 to $190 \mathrm{~g} \mathrm{~mol}^{-1}$ ).

Table 3. SG and WL of melon dehydrated with sucrose and grape juice concentrate ( $60{ }^{\circ} \mathrm{Brix}$ ), for $1 \mathrm{~h}$ at $40^{\circ} \mathrm{C}$, and fruit ratio:osmotic agent of $1: 10$ at different absolute pressures.

\begin{tabular}{|r|c|c|c|c|c|c|}
\hline \multirow{2}{*}{$\begin{array}{l}\text { Pressure } \\
(\mathbf{m b a r})\end{array}$} & \multicolumn{2}{|c|}{ SG $\left(\mathbf{g ~ g}^{-1}\right.$ melon) } & \multicolumn{2}{c|}{ WL $\left(\mathbf{g ~ g}^{-1}\right.$ melon) } & \multicolumn{2}{c|}{ WL/SG } \\
\cline { 2 - 7 } & SS & GJC & SS & GJC & SS & GJC \\
\hline 200 & $0.08 \pm 0.01^{\mathrm{Aa}}$ & $0.05 \pm 0.01^{\mathrm{bA}}$ & $-0.35 \pm 0.01^{\mathrm{bA}}$ & $-0.51 \pm 0.01^{\mathrm{aB}}$ & $4.3 \pm 0.6^{\mathrm{aB}}$ & $11.2 \pm 1.2^{\mathrm{aA}}$ \\
\hline 400 & $0.10 \pm 0.02^{\mathrm{aA}}$ & $0.10 \pm 0.01^{\mathrm{aA}}$ & $-0.30 \pm 0.01^{\mathrm{abA}}$ & $-0.47 \pm 0.01^{\mathrm{aB}}$ & $3.0 \pm 0.6^{\mathrm{abA}}$ & $4.9 \pm 0.4^{\mathrm{bA}}$ \\
\hline 600 & $0.12 \pm 0.01^{\mathrm{aA}}$ & $0.09 \pm 0.02^{\mathrm{aA}}$ & $-0.28 \pm 0.01^{\mathrm{aA}}$ & $-0.47 \pm 0.06^{\mathrm{aB}}$ & $2.3 \pm 0.1^{\mathrm{bB}}$ & $5.2 \pm 0.3^{\mathrm{bA}}$ \\
\hline
\end{tabular}

Lowercase letters in the same column and capital letters in the same line (within the same parameter) indicate significant differences $(\mathrm{p}<0.05)$.

\section{Mechanical properties}

Fresh melon showed true stress values at rupture of $145.5 \pm 31.6 \mathrm{kPa}$, Hencky's strain at rupture of $0.26 \pm 0.07$, and deformability modulus of $884.3 \pm 135.1 \mathrm{kPa}$, which resulted in a firm product with low deformation, despite the variable mechanical behavior. Therefore, the results obtained after OD were normalized with their corresponding fresh melons to eliminate this effect (Table 4). Values lower or higher than one indicate decrease or increase of the parameter, respectively.

Table 4. Standard mechanical properties of OD melon with sucrose solution (SS) and grape juice concentrate (GJC) at different vacuum pressures

\begin{tabular}{|c|c|c|c|c|c|c|}
\hline \multirow{2}{*}{$\begin{array}{l}\text { Pressure } \\
\text { mbar) }\end{array}$} & \multicolumn{2}{|c|}{$\begin{array}{c}\text { True stress values at } \\
\text { rupture }\end{array}$} & \multicolumn{2}{c|}{$\begin{array}{c}\text { Hencky's strain at } \\
\text { rupture }\end{array}$} & \multicolumn{2}{c|}{ Deformability modulus } \\
\cline { 2 - 7 } & $\mathrm{SS}$ & $\mathrm{GJC}$ & $\mathrm{SS}$ & $\mathrm{GJC}$ & $\mathrm{SS}$ & $\mathrm{GJC}$ \\
\hline 200 & $0.83 \pm 0.16^{\mathrm{aB}}$ & $1.74 \pm 0.08^{\mathrm{aA}}$ & $1.74 \pm 0.04^{\mathrm{aB}}$ & $3.26 \pm 0.32^{\mathrm{aA}}$ & $0.41 \pm 0.01^{\mathrm{bB}}$ & $0.63 \pm 0.03^{\mathrm{aA}}$ \\
\hline 400 & $1.16 \pm 0.02^{\mathrm{aB}}$ & $2.07 \pm 0.12^{\mathrm{aA}}$ & $1.87 \pm 0.01^{\mathrm{aB}}$ & $4.19 \pm 0.07^{\mathrm{aA}}$ & $0.58 \pm 0.06 \mathrm{a}^{\mathrm{bA}}$ & $0.50 \pm 0.01^{\mathrm{aA}}$ \\
\hline 600 & $1.23 \pm 0.08^{\mathrm{aA}}$ & $1.62 \pm 0.17^{\mathrm{aA}}$ & $1.83 \pm 0.1^{\mathrm{aB}}$ & $3.52 \pm 0.45^{\mathrm{aA}}$ & $0.67 \pm 0.07^{\mathrm{aA}}$ & $0.47 \pm 0.08^{\mathrm{aA}}$ \\
\hline
\end{tabular}

Lowercase letters in the same column and capital letters in the same line (within the same parameter) indicate significant differences $(\mathrm{p}<0.05)$. 
No significant effects of the different pressure conditions were observed on the mechanical behavior of melon subjected to osmotic dehydration using the GJC or sucrose solution, indicating that the mechanical behavior was a function of the concentration of solids in the dried samples, which was significant different (Table 4). The type of osmotic agent had a significant effect on the mechanical behavior of melon. Therefore, melon subjected to OD with GJC showed greater ability to resist compression (high stress values at rupture) when compared with the melon dehydrated with sucrose solution under different pressures. The increase in melon firmness was due to the high water loss during OD, which resulted in low moisture content (Table 2). Moreover, melon dehydrated with GJC had more plasticity (high Hencky's strain values) during compression, probably due to its soluble solids content (Table 2). A lower elasticity (low deformability modulus values) was observed in melon dehydrated with GJC and with sucrose solution, without significant differences among them.

The mechanical properties of fruits and vegetables have been associated with different structural levels of the material [18]. At the microstructural level, some elements are relevant to the texture, including the structure and chemical characteristics of the plant cell wall, wall thickness, cell turgor pressure, and strength and nature of cell-to-cell adhesion. At higher structural levels, the tissue structure (cell orientation, and amount of intercellular spaces) and the different types of tissue or organs forming part of the vegetable product are also relevant. Changes in these parameters were observed in the morphological analysis, and will be discussed hereafter.

\section{Appearance and morphology of osmotically dehydrated melon}

Melon dehydrated with sucrose solution and GJC presented, respectively, a slight pale yellow color and a dark red color (Figure 1). After OD with sucrose and GJC solutions, a decrease in volume of melons was observed, with percentages of $19.7 \%$ and $47.2 \%$ respectively, due to high water loss (Table 3). There were no differences in appearance (to the naked eye) of dehydrated melon as a function of the pressure applied.
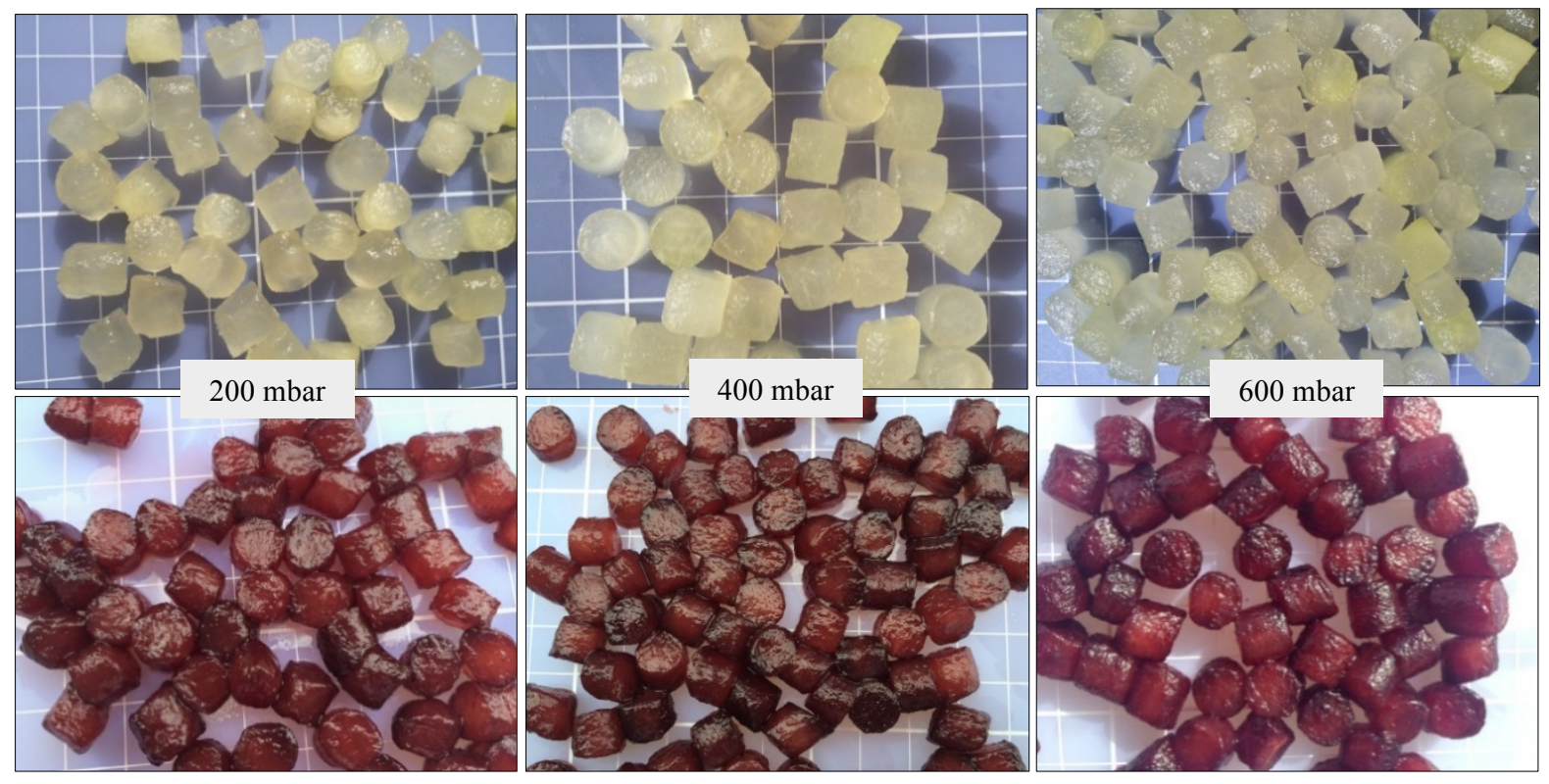

Figure 1. Images of melon dehydrated with sucrose solution and grape juice concentrate at 200 mbar, 400 mbar, and $600 \mathrm{mbar}$ at $40{ }^{\circ} \mathrm{C}$ for 1 hour using fruit ratio:osmotic agent of 1:10. 
Images of fresh melon showed turgid cells with the plasmalemma in close contact with the cell wall, with small and triangular intercellular spaces (Figure 2). Cells were mostly rounded, with different sizes. Some cells have thin and well defined cell wall (Figure 2a) and others have thick cell wall with small dimples (Figure $2 b, c$ ), as a result of the softened tissue due to ripening. Several factors including cell turgor, force with which cell middle lamella joins together, and cell wall compression strength have contributed to the results in the mechanical properties of fresh melon.

Significant changes in the cell structure of melons were not observed with variation of pressure, as also observed for the mechanical properties. In practice, it is not possible to study melons with exactly the same cell structure, thus it is difficult to assess the effect of variation of pressure on the melon cellular structure, and consequently on its mechanical behavior. This is because the initial morphology of the cell has an important influence on the response to the OD process [28]. The main changes in the present study were due to the type of osmotic agent used in the process. The use of GJC led to significant changes in the melon cellular structure (Figure 2). In a first assessment, a more preserved cellular structure was observed in the melon dehydrated with sucrose solution, in addition to cells destroyed in the melon dehydrated with GJC. Thus, in general the water loss of melon resulted in the deformation of the cell walls, decreased turgor pressure in cells, and plasmolysis.
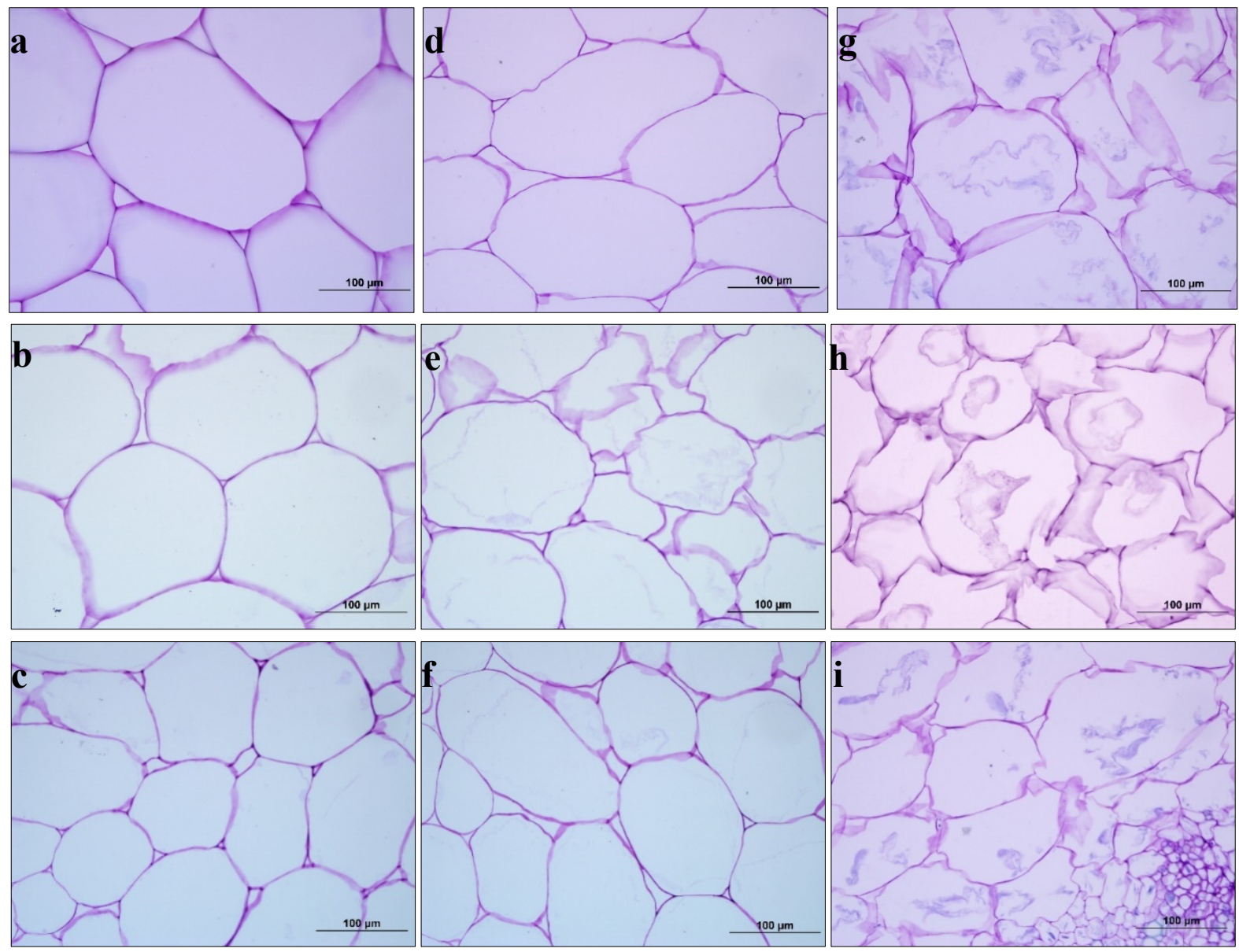

Figure 2. Mesocarp cross sections of fresh melon $(a, b, c)$ subjected to osmotic dehydration with sucrose solution $(\mathrm{d}=200 \mathrm{mbar}$; and $\mathrm{e}=400 \mathrm{mbar} ; \mathrm{f}=600 \mathrm{mbar})$ and grape juice concentrate $(\mathrm{g}=$ 200 mbar; $\mathrm{h}=400$ mbar; $\mathrm{i}=600 \mathrm{mbar}$ ). 
The OD with sucrose solution resulted in an increase in intercellular spaces (Figure 2def), with partial plasmalemma detachment from cell wall surface (Figure 2e), increased undulations (Figure 2e), cell wall thickening (Figure 2d, e), and loss of the initial cell shape. Consequently, the dehydrated melon presented larger deformation (Table 4), reduced elasticity, and equal resistance to compression when compared to fresh melon. Sucrose diffusion into the melon cellular matrix (during OD) and its interaction with the polymers of the pectic acid in the cell wall and middle lamella, and low water content may result in the formation of a gel structure, increasing consistency of the tissue, contributing to the increase in plasticity, decrease in elasticity, and maintenance of resistance to tissue compression.

Melon dehydrated with GJC showed plasmolysis of cell membranes at all pressures studied. Water content determines the cell volume, so that cell volume decreased when water flows through the osmotic environment. When the cell wall that is the most rigid part of the cell does not decrease in volume, the inner cell terminated by the plasma membrane continues to decrease, detaching this biomembrane from the cell wall. In some cases, a rounded vesicle is formed inside the cell (Figure $2 \mathrm{~h}$ ) and in other cases the vesicle is practically destroyed (Figure 2ghi). The detachment of the plasmalemma was not uniform, and attached to the cell wall, showing collapsed plasmalemma due to cell water output to the osmotic environment. The cells become deformed, but are still connected to each other, with no increase in intercellular space and cell wall thickening. These findings evidenced the formation of links between cell wall components, the middle lamella, and plasmalemma which keep these membranes together. GJC contains different minerals in its composition, including calcium that can form crosslinking with the free carboxyl groups of the pectin chains in these membranes, enhancing cellular adhesion and reducing their separation. The low GJC $\mathrm{pH}(3.03 \pm 0.02)$ (Table 1) favors these interactions because the pectin has a negative charge at this $\mathrm{pH}(\mathrm{pKa}$ pectin $=3.6-4.1)$.

Calcium salts are used to improve firmness of fruits submitted to the OD process, and calcium lactate is the preferred salt once it does not confer bitter taste to the fruit [17]. The amount of calcium lactate used in OD processes range from 5 to $40 \mathrm{~g} \mathrm{~kg}^{-1}$ osmotic solution [17, 29,30 ], corresponding to calcium concentrations between $650-5200 \mathrm{mg} \mathrm{kg}^{-1}$. GJC has a calcium content of $506 \pm 5 \mathrm{mg} \mathrm{kg}^{-1}$ (wet basis) which corresponds to the calcium present in a sucrose solution containing calcium lactate at a concentration of $3.9 \mathrm{~g} \mathrm{~kg}^{-1}$. Thus, the calcium in GJC improved the tissue mechanical properties because it was incorporated into the melon matrix and interacted with pectins and other cell wall components, modifying the cellular structure of melon and contributing to its firmness. The type of structure formed (open or close network) as a result of the interaction between calcium and pectin affects the mass transfer. In the process conducted with GJC, in addition to high water loss, a high solute gain was expected, once solutes in the GJC have low molecular mass (glucose and fructose). However, the solute gain was prevented probably due to the type of network formed. Some authors have reported that the presence of calcium lactate in the sucrose solution used to dehydrate apple improved OD efficiency, which was associated with reduced cell wall porosity due to formation of calcium pectate [29]. In this study, low $\mathrm{pH}$ and the presence of calcium in the GJC affected the solute gain, which together with the high water loss of melon matrix, led to a high efficiency of the OD process (Table 2). The changes in cellular structure along with the soluble solids content and low moisture affected the mechanical behavior of melon cellular matrix, resulting in a firmer product, with higher deformation and less elasticity (Table 4). 


\section{Antioxidant capacity and calcium content}

As expected, higher antioxidant capacity was observed for grape juice concentrate when compared to other products (Table 5), since the analysis was carried out in grape juice concentrate $\left(60^{\circ}\right.$ Brix $)$. Grape and its derivatives are considered products with a high antioxidant potential, capable of preventing oxidative processes in the organism [1]. The antioxidant capacity of melon increased significantly after the OD at 600 mbar with GJC, indicating that the melon has been enriched with antioxidant solutes present in the juice. Antioxidant capacity of melon dehydrated at 200 and 400 mbar was not determined because melon physical characteristics in those pressures were similar to those obtained at 600 mbar. Furthermore, the antifoam agent was not required at high pressures. No changes in the antioxidant capacity were observed after drying with hot air at 50 and $70^{\circ} \mathrm{C}$, showing that the combination of two processes was effective to obtain a product with low water activity without affecting its antioxidant capacity. Moreover, the active components of GJC can be protected by their inclusion within the melon structure. Vitamins, minerals, and probiotic microorganisms dispersed in sucrose solution have been incorporated into fruits and vegetables through the vacuum impregnation technology, which is applied intermittently during the process [31]. The advantage of using GJC in the OD process is that it can be more effective than active components alone, since the physiological effect of a single component differs in the presence of other components due to synergistic effects.

Table 5. Antioxidant capacity and calcium content of the raw material and final products obtained after osmotic and hot air dehydration.

\begin{tabular}{|c|c|c|c|c|}
\hline \multirow{2}{*}{ Samples } & \multicolumn{3}{|c|}{ Antioxidant capacity $\left(\mu \mathrm{mol} \mathrm{TE} \mathrm{g}^{-1}\right.$, d.b.) } & \multirow{2}{*}{$\begin{array}{c}\text { Calcium } \\
\left(\mu \mathrm{g} \mathrm{g}^{-1}, \mathrm{~d} . \mathrm{b} .\right)\end{array}$} \\
\hline & DPPH & ABTS & ORAC & \\
\hline Fresh melon & n.d. & $5.54 \pm 0.17^{d}$ & $50.23 \pm 3.98^{c}$ & $279.97 \pm 12.32$ \\
\hline Grape juice concentrate & $63.16 \pm 0.78^{\mathrm{a}}$ & $79.28 \pm 2.55^{\mathrm{a}}$ & $320.39 \pm 15.89^{\mathrm{a}}$ & $816.75 \pm 7.98$ \\
\hline Dehydrated melon 1 & $15.65 \pm 0.52^{\mathrm{c}}$ & $29.00 \pm 0.97^{\mathrm{b}}$ & $123.29 \pm 3.73^{\mathrm{b}}$ & $772.11 \pm 3.52$ \\
\hline Dehydrated melon 2 & $18.70 \pm 0.30^{\mathrm{b}}$ & $27.93 \pm 1.72^{\mathrm{bc}}$ & $110.40 \pm 13.71^{\mathrm{b}}$ & $921.89 \pm 9.26$ \\
\hline Dehydrated melon 3 & $19.38 \pm 0.51^{\mathrm{b}}$ & $26.03 \pm 0.48^{\mathrm{c}}$ & $94.01 \pm 13.37^{\mathrm{b}}$ & $916.73 \pm 21.95$ \\
\hline
\end{tabular}

Dehydrated melon 1 - with GJC; Dehydrated melon 2 and 3 - with GJC followed by air-drying process ant 50 and $70^{\circ} \mathrm{C}$, respectively; TE - Trolox equivalent; n.d. - not determined by the method; d.b. - dry basis. Lowercase letters in the same column indicate significant differences $(\mathrm{p}<0.05)$.

Among the three methods used to evaluate the antioxidant capacity, the ORAC method provided the highest values, and the DPPH method proved to be the least sensitive, with values close to those obtained with the ABTS method. These results are in agreement with the results obtained for grape juice, in which the DPPH method was less sensitive, and ORAC was the most sensitive method [32]. The ORAC method has a very important advantage when compared to other absorption spectroscopy methodologies using fluorescence as a measure of oxidative damage, since less interference occurs from colored compounds present in samples, such as in grape juice. The method measures the ability of an antioxidant to protect protein (fluorescein) from oxidative damage caused by peroxyl radicals (biologically relevant), and can be used to measure both hydrophilic and lipophilic antioxidants [33]. In this study, only the antioxidant capacity of hydrophilic compounds was investigated. 
Vacuum OD proved to be a useful process for incorporating calcium from the GJC to the melon structure, in a quick and simple manner. The calcium content (dry basis) of fresh melon increased from $280 \mu \mathrm{g} \mathrm{g}^{-1}$ to $772-922 \mu \mathrm{g} \mathrm{g}^{-1}$ in the sample subjected to OD and conventional drying, which was similar to the calcium concentration in the GJC (817 $\left.\mu \mathrm{g} \mathrm{g}^{-1}\right)$. Although the calcium content was lower than other fortified products [29, 34], its intestinal absorption should be facilitated due to the acidic $\mathrm{pH}$ of dehydrated melon $(\mathrm{pH}=3.8 \pm 0.02)$ that contributes to the calcium ionization, besides reducing the inhibitory effect of dietary phytic acid on calcium bioavailability [35]. Several commercial calcium salts have been used for calcium enrichment of different products, including calcium carbonate, calcium chloride, calcium phosphate, tribasic calcium phosphate, calcium citrate malate, calcium lactate, calcium gluconate, calcium lactate gluconate, as well as milk's calcium [35]. The disadvantage of these salts is that they contain very low amounts of elemental calcium. For example, calcium lactate ( $13 \%$ elemental calcium) requires the addition of high amounts to the osmotic solution. It is noteworthy that calcium is one of the most important minerals and is required for growth, maintenance, and reproduction of the human body.

\section{Sensory analysis}

High variability was observed among the sensory scores, with coefficients of variation around 29\% (Table 6). Among the products evaluated, significant differences were observed only for the attribute taste, with high scores for melon subjected to OD, which contributed to the overall impression of the product, with values ranging between 4.8 and 8.4. No significant differences were observed for appearance, aroma, color, and texture among the products (Table 6), indicating no effects of hot air on the dehydration process. Although the melon submitted to the osmotic process presented water activity greater than the melon submitted to osmotic process and hot air dehydration, this was not perceived by the panelists in the texture attribute. All scores assigned to the samples remained above the acceptable limit ( $>5)$, varying between slightly like to moderately like, resulting in purchase intention with average scores between 3 and 4, indicating that likelihood of purchasing the product. The visual impact of the product is decisive for acquisition by the consumer, which may have led to a negative purchase intention, since the attribute appearance had the lowest score in relation to the other attributes.

Table 6. Scores obtained from the panelists for melon samples dehydrated with grape juice concentrate and with hot air.

\begin{tabular}{lccc}
\hline \multirow{2}{*}{ Attributes } & \multicolumn{3}{c}{ Dehydrated melon } \\
\cline { 2 - 4 } & $\mathbf{1}$ & $\mathbf{2}$ & $\mathbf{3}$ \\
\hline Appearance & $5.8 \pm 1.8^{\mathrm{a}}$ & $5.5 \pm 1.8^{\mathrm{a}}$ & $5.4 \pm 1.6^{\mathrm{a}}$ \\
Color & $5.8 \pm 1.9^{\mathrm{a}}$ & $5.5 \pm 1.8^{\mathrm{a}}$ & $5.7 \pm 1.9^{\mathrm{a}}$ \\
Aroma & $6.1 \pm 1.6^{\mathrm{a}}$ & $6.3 \pm 1.6^{\mathrm{a}}$ & $6.2 \pm 1.4^{\mathrm{a}}$ \\
Taste & $6.6 \pm 1.8^{\mathrm{a}}$ & $5.8 \pm 2.2^{\mathrm{b}}$ & $5.4 \pm 2.2^{\mathrm{b}}$ \\
Texture & $6.1 \pm 2.0^{\mathrm{a}}$ & $5.8 \pm 2.0^{\mathrm{a}}$ & $6.1 \pm 1.7^{\mathrm{a}}$ \\
Overall acceptance & $6.3 \pm 1.7^{\mathrm{a}}$ & $5.9 \pm 1.7^{\mathrm{ab}}$ & $5.5 \pm 1.8^{\mathrm{b}}$ \\
\hline
\end{tabular}

1-with GJC; 2-with GJC followed by air-drying process at $50^{\circ} \mathrm{C} ; 3$ - with GJC followed by air-drying process at $70^{\circ} \mathrm{C}$. Lowercase letters in the same column indicate significant differences $(\mathrm{p}<0.05)$. 


\section{CONCLUSIONS}

Dehydrated melon with similar physical characteristics including moisture content, soluble solids content, mechanical and morphological properties can be obtained using absolute pressures from 200 to 600 mbar in the osmotic dehydration process. The use of GJC as osmotic agent results in high efficiency of dehydration and high water activity lowering capacity when compared to sucrose solution. The marked changes caused by GJC in the melon cellular matrix did not directly affect the mechanical properties. Calcium present in GJC was impregnated into the melon matrix and interacted with pectin, and other cell wall components, resulting in a firmer product. Both osmotic and hot air dehydration processes can be combined to obtain a product with intermediate moisture, without affecting their antioxidant capacity. Finally, a product with low water activity, firmer texture, higher antioxidant capacity, rich in calcium, and potential sensory acceptance can be obtained using grape juice concentrate in the osmotic dehydration process.

\section{Authors' contributions}

Chambi HNM and Schmidt FL were responsible for study design and review the manuscript. Chambi HNM was responsible for preparing the research protocols, determination of antioxidant capacity, interpretation of data and writing the manuscript. Arid JD was responsible for experimental process, laboratory assays and statistical analysis. All author read and approved the final manuscript.

\section{Acknowledgements}

The authors thank Sandra Maria Carmello Guerreiro, PhD, Professor of Biology Institute (IB, Unicamp, Brazil) by advising in morphological analysis of melon; and Eduardo Adilson Orlando of Food Analysis Laboratory II (FEA, Unicamp, Brazil) for the technical support in calcium determination. To Coordination for the Improvement of Higher Education Personnel (CAPES) for the Postdoctoral Fellowship of the first author; and State University of Campinas for the Undergraduate Research Fellowship of the second author.

\section{REFERENCES}

1. Park YK, Park E, Kim J-S, Kang M-H: Daily grape juice consumption reduces oxidative DNA damage and plasma free radical levels in healthy Koreans. Mutat Res 2003, 529:7786.

2. Wang H, Cao G, Prior RL: Total Antioxidant Capacity of Fruits. J Agric Food Chem 1996, 44:701-705.

3. Vislocky LM, Fernandez ML: Biomedical effects of grape products. Nutr Ver 2010, 68:656-670.

4. Wightman JD, Heuberger RA: Effect of grape and other berries on cardiovascular health. J Sci Food Agric 2015, 95:1584-1597.

5. Blumberg JB, Vita JA, Oliver Chen CY: Concord grape juice polyphenols and cardiovascular risk factors: Dose-response relationships. Nutrients 2015, 7:10032-10052. 
6. Giovanelli G, Brambilla A, Sinelli N: Effects of osmo-air dehydration treatments on chemical, antioxidant and morphological characteristics of blueberries. LWT - Food Sci Technol 2013, 54:577-584.

7. Ruiz-López II, Ruiz-Espinosa H, Herman-Lara E, Zárate-Castillo G: Modeling of kinetics, equilibrium and distribution data of osmotically dehydrated carambola (Averrhoa carambola L.) in sugar solutions. J Food Eng 2011, 104:218-226.

8. Escriche I, Garcia-Pinchi R, Carot JM, Serra JÁ: Comparison of must and sucrose as osmotic solutions to obtain high quality minimally processed kiwi fruit (Actinidia chinensis P.) slices. Int J Food Sci Technol 2002, 37:87-95.

9. Chambi HNM, Lima WCV, Schmidt FL: Osmotic dehydration of yellow melon using red grape juice concentrate. Food Sci Technol 2016, in press.

10. Chiralt A, Martínez-Navarrete N, Martínez-Monzó J, Talens P, Moraga G, Ayala A, Fito P: Changes in mechanical properties throughout osmotic processes cryoprotectant effect. J Food Eng 2001, 49:129-135.

11. Prinzivalli C, Brambilla A, Maffi D, Scalzo RL, Torreggiani D: Effect of osmosis time on structure, texture and pectic composition of strawberry tissue. Eur Food Res Technol 2006, 224:119-127.

12. Martinez-Monzo J, Martinez-Navarrete N, Chiralt A, Fito P: Mechanical and structural changes in apple (var. Granny Smith) due to vacuum impregnation with cryoprotectants. J Food Sci 1998, 63:499-503.

13. Ahmed I, Qazi IM, Jamal S: Developments in osmotic dehydration technique for the preservation of fruits and vegetables. Innov Food Sci Emerg Technol 2016, 34:29-43.

14. Nanasombat S, Thonglong J, Jitlakha J: Formulation and characterization of novel functional beverages with antioxidant and anti-acetylcholinesterase activities. Funct Foods Heal Dis 2015, 5:1-16.

15. Mújica-Paz H, Valdez-Fragoso A, López-Malo A, Palou E, Welti-Chanes J: Impregnation and osmotic dehydration of some fruits: effect of the vacuum pressure and syrup concentration. J Food Eng 2003, 57:305-314.

16. Khin MM, Zhou W, Perera CO: Impact of process conditions and coatings on the dehydration efficiency and cellular structure of apple tissue during osmotic dehydration. J Food Eng 2007, 79:817-827.

17. Ferrari CC, Carmello-Guerreiro SM, Bolini HMA, Hubinger MD: Structural Changes, Mechanical Properties and Sensory Preference of Osmodehydrated Melon Pieces with Sucrose and Calcium Lactate Solutions. Int J Food Prop 2010, 13:112-130.

18. Mayor L, Cunha RL, Sereno AM: Relation between mechanical properties and structural changes during osmotic dehydration of pumpkin. Food Res Int 2007, 40:448-460.

19. Luza JG, van Gorsel R, Polito VS, Kader AA: Chilling Injury in Peaches: A Cytochemical and Ultrastructural Cell Wall Study. J Amer Soc Hort Sci 1992, 117:114-118.

20. Re R, Pellegrini N, Proteggente A, Pannala A, Yang M, Rice-Evans C: Antioxidant activity applying an improved ABTS radical cation decolorization assay. Free Radic Biol Med 1999, 26:1231-1237.

21. Brand-Williams W, Cuvelier ME, Berset C: Use of a free radical method to evaluate antioxidant activity. LWT - Food Sci Technol 1995, 28:25-30. 
22. Ou B, Chang T, Huang D, Prior RL: Determination of total antioxidant capacity by oxygen radical absorbance capacity (ORAC) using fluorescein as the fluorescence probe: first action 2012.23. J AOAC Int 2013, 96:1372-1376.

23. Boen TR, Soeiro BT, Pereira-Filho ER, Lima-Pallone JÁ: Folic acid and iron evaluation in Brazilian enriched corn and wheat flours. J Braz Chem Soc 2008, 19:53-59.

24. Meilgaard M, Vance Civille G, Thomas Carr B: Sensory evaluation techniques. $3^{\text {th }}$ edit. New York: CRC Press; 1999.

25. Corrêa JLG, Pereira LM, Vieira GS, Hubinger MD: Mass transfer kinetics of pulsed vacuum osmotic dehydration of guavas. J Food Eng 2010, 96:498-504.

26. Nieto AB, Vicente S, Hodara K, Castro MA, Alzamora SM: Osmotic dehydration of apple: Influence of sugar and water activity on tissue structure, rheological properties and water mobility. J Food Eng 2013, 119:104-114.

27. Le Bourse D, Jégou S, Conreux A, Villaume S, Jeandet P: Review of preparative and analytical procedures for the study of proteins in grape juice and wine. Anal Chim Acta 2010, 667:33-42.

28. Seguí L, Fito PJ, Fito P: A study on the rehydration ability of isolated apple cells after osmotic dehydration treatments. J Food Eng 2013, 115:145-153.

29. Mauro MA, Dellarosa N, Tylewicz U, Tappi S, Laghi L, Rocculi P, Rosa MD: Calcium and ascorbic acid affect cellular structure and water mobility in apple tissue during osmotic dehydration in sucrose solutions. Food Chem 2016, 195:19-28.

30. Torres JD, Talens P, Escriche I, Chiralt A: Influence of process conditions on mechanical properties of osmotically dehydrated mango. J Food Eng 2006, 74:240-246.

31. Betoret E, Sentandreu E, Betoret N, Codoñer-Franch P, Valls-Bellés V, Fito P: Technological development and functional properties of an apple snack rich in flavonoid from mandarin juice. Innov Food Sci Emerg Technol 2012, 16:298-304.

32. Tabart J, Kevers C, Pincemail J, Defraigne J-O, Dommes J: Comparative antioxidant capacities of phenolic compounds measured by various tests. Food Chem 2009, 113:12261233.

33. Schaich KM, Tian X, Xie J: Reprint of "Hurdles and pitfalls in measuring antioxidant efficacy: A critical evaluation of ABTS, DPPH, and ORAC assays". J Funct Foods 2015, 18:782-796.

34. Barrera C, Betoret N, Corell P, Fito P: Effect of osmotic dehydration on the stabilization of calcium-fortified apple slices (var. Granny Smith): Influence of operating variables on process kinetics and compositional changes. J Food Eng 2009, 92:416-424.

35. Singh G, Muthukumarappan K: Influence of calcium fortification on sensory, physical and rheological characteristics of fruit yogurt. LWT - Food Sci Technol 2008, 41:1145-1152. 